\title{
THE INSTITUTIONAL EMPOWERMENT BUILDING OF THE THETHELAN (CROPS) FARMER ON REHABILITATION ZONE OF MERU BETIRI (TNMB) NATIONAL PARK IN EAST JAVA
}

\author{
Drs. Joko Mulyono, M.Si, Lukman Wijaya Baratha, S.Sos, MA \\ dan Ahmad Munif Mubarok, S.Sos,M.Si \\ Department of Sociology, University of Jember, Jember, Indonesia \\ by \\ (gusmoel@gmail.com)
}

\begin{abstract}
The study entitled "The institutional empowerment building of the crops farmer on rehabilitation zone of Meru Betiri national park in East Java" takes the fact that since the initialization of the Ecosystem Returns (PE) in 1999 in the rehabilitation zone until the year 2017, there is no optimum result of the program. Instead of getting greener, the zone becomes more dry, arid, and wither. The problem of the study is that what causes the PE program in rehabilitation zone ran less optimum? How to build the institutional empowerment of crops farmer? The purpose of this study is to identify factors that cause the less optimum of PE program at the rehabilitation zone and to formulate the model of optimum institutional empowerment of crops farmers. The primary data were through observation, interview, and Focus Group Discussion (FGD), while the secondary data were from a mixed document of Green's ecological theory and Nort's institution theory. Less optimum of PE program is due to the cultural switch from abstinence to anthropocentric, the scarcity of farming land, and market intervention. The model of institutional empowerment of crops farmer is the cooperation and synergy interaction among the actors.
\end{abstract}

Keywords: cooperative interaction, institutional, empowerment, farmers

\section{Introduction}

National park refers to conservation with the original ecosystem and is managed with a zonation system. In more detail, the National Park is useful for research purpose, knowledge, education, educational support, tourism, recreation, and to take advantage sustainably from its natural resources and ecosystem; its well-known as living monument. The Meru Betiri National Park (TNMB) has several missions, as other national parks do, namely:
1. Protection on a life support system,

2. The preservation of biodiversity of plants and animal along with the ecosystem, and

3. The sustainable utilization of natural resources and its ecosystem.

The basic principles are supported by the Indonesian government through the appointment of Meru Betiri National Park (TNMB) in accordance to the Decree of Forestry Ministry No. 277/Kpts-VI/1997 dated May 23, 1997, on the transformation 
of Meru Betiri Wildlife Conservation to Meru Betiri National Park (TNMB). The decree also explains the characteristics of forest area division using a zonation system.

Tabel 1. TNMB Zone Division

\begin{tabular}{|c|l|r|}
\hline No. & \multicolumn{1}{|c|}{ Zone } & \multicolumn{1}{c|}{ Landmass } \\
\hline 1. & Core zone & $28.707 .7 \mathrm{Ha}$ \\
\hline 2. & Forest zone & $28.707 .622 \mathrm{Ha}$ \\
\hline 3. & $\begin{array}{l}\text { Maritime protection } \\
\text { zone }\end{array}$ & $273.3 \mathrm{Ha}$ \\
\hline 4. & Utilization zone & $2.733 .5 \mathrm{Ha}$ \\
\hline 5. & Rehabilitation zone & $285.3 \mathrm{Ha}$ \\
\hline 6. & Traditional zone & $345 \mathrm{Ha}$ \\
\hline 7. & Special zone & $58.000 \mathrm{Ha}$ \\
\hline
\end{tabular}

Sumber data: Statistik B TNMB 2015

The Approval Letter of Directorate General of PHKA the year 1998 and the MoU of the Directorate General of PHKA the year 1999 on the society rehabilitation activity regulate the management of rehabilitation zone; the program that consists of several categories.

a. The community may cultivate the rehabilitation zone at Meru Betiri National Park.

b. Communities should plant staple crops in the form of an authentic plant (endemic) that has medical benefits and some others; the plant of which its seed is available at TNMB office and a free market.

c. The community may plant intercropping plants between the main crops

d. TNMB restricts the planting of plantation crops such as cocoa, coffee, tobacco, etc. Staple crops in the form of fruit are the rights of the sharecroppers while the trees cannot be cut down and are TNMB assets.

e. The land belongs to the state and cannot be converted to ownership or another status. The community should assist the TNMB to secure its area along with Forest Ranger and TNMB Office.

The following is the land area of rehabilitation zone that becomes the focus of this study. Two villages that became the sample of the study which existed nearby the TNMB.

Tabel 2. The Land Area of Rehabilitation Zone Tenancy Sample of Two Villages

\begin{tabular}{|c|l|c|c|c|}
\hline No & Village & $\begin{array}{c}\text { Land } \\
\text { area in } \\
\text { Ha }\end{array}$ & $\begin{array}{c}\text { The } \\
\text { farmer's } \\
\text { number }\end{array}$ & $\begin{array}{c}\text { Average/ } \\
\text { person }\end{array}$ \\
\hline 1. & Wonoasri & 1.054 .2 & $\begin{array}{c}(21 \mathrm{Kelp} .) \\
498 \text { orang }\end{array}$ & $2,1 \mathrm{Ha}$ \\
\hline 2 & Andongrejo & 742.2 & $\begin{array}{c}(19 \mathrm{Kelp} .) \\
538 \text { orang }\end{array}$ & $1,4 \mathrm{Ha}$ \\
\hline \multicolumn{2}{|c|}{ Jumlah } & $1.796,4$ & 1.036 orang & $1,7 \mathrm{Ha}$ \\
\hline
\end{tabular}

Data source: Secondary Processed Statistic BTNMB the year 2016

The management of rehabilitation zone by the TNMB according to the above table is by involving the farmers of forest buffer through organizing the community to regulate the attempts of running proper management as in the government program in securing the national park accordingly. There are 21 groups of leased communitylands in Wonosari village with 498 members, and 19 groups with 538 members. Each group has two members that belong to the two buffering villages that have an average leased land of $1.7 \mathrm{Ha}$ or less than six pathok. One pathok equals to a quarter of 
Ha. In addition to the freedom to use the rehabilitation zone for the farmers, the TNMB provides other benefit for the community in the form of society empowerment to cultivate the land provided, such as the strengthening of the community institution, socialization on program planning, training, plant seeds cultivation support such as herbs, ginger, the production of organic fertilizer, farming tools, and capital.

In its practice, the $\mathrm{PE}$ program that has been running for seventeen years cannot fulfill the initial expectation. TNMB expects the farmers to support the PE program, or at least they can perform better conduct and reduce violations as the ideal goals of the forming a community. However, the farmers still conduct some act that violates the agreement and $\mathrm{MoU}$ in the institution. The buffering farmers' action to burn the farming area and the seeds lifting of the crops resulted in the degradation and crisis of forest especially the rehabilitation zone and other regions in TNMB.

The environmental crisis is a result of chain reaction of a phenomena surrounding the TNMB which will cause pollution of air, sea, river, and land, toxicity in food chain, the extinction of certain types of animal and wildlife, erosion of the land surface, deforestation, and population crisis (Tesorioero: 2008). This crisis already exists in TNMB area in the form of seasonal flood in Wonosari as the spillover of the upstream river in Saninrejo village (the buffering village), the devastation of ecosystem and natural resources, the decrease of water volume and quality, the landslide potential, the existent of arid and barren land, forest fire, and other devastating occurrence; this is in contrary with the initial expectation to have TNMB as the living monument with numerous benefits. The statement of problems are why the Ecosystem restoration program $(\mathrm{PE})$ in the rehabilitation zone cannot achieve its optimum result? What are things to take in building the institutional empowerment of crops farmers in rehabilitation zone?

\section{Theoretical Review}

The government's policy has failed to overcome the structural poverty issue in villages is the cause for the people to commit criminal conduct towards forests. The argumentation appears in this issue is the existence of double review towards the conflict between the state's control culture and community resistance that is resulting in the social strain, and environmental decay. Peluso stated that while the state acts as the agent of conservation by using the conservation ideologies to take coercive steps to gain the state's control over the resources, the environment appears as the political, economic, and ideological conflict (Peluso in Seda (2006:26) Jurnal Labsos "Masyarakat" UI. .

According to Green, the effective way to overcome the ecological crisis is through social, economic, and political change; that 
is more promising than advancing knowledge and technology. The community work has the potential as one of the effective ways to develop a sustainable society (Tesoriero:2008,56) Further, a collective or community system can achieve better protection for the environment and natural resources. Therefore, a transition in the socialist community is necessary and mandatory in response to the ecological crisis.

Green's point of view is very crucial in responding to the development of $\mathrm{CO} /$ CD community by focusing on holism, sustainability, diversity, and balance. Holism is the situation to see that every occurrence as a whole. Therefore, every aspect has a relation and interaction with other elements. The TNMB, farmer community, market and other sub-systems in the TNMB management, in general, and in $\mathrm{PE}$ program, in specific, is a unity of interaction system. Sustainability means that a system must be maintained for a long period and that new sources of energy are used and limited, and the consumption is minimized. The organism diversity and system are improving to fulfill the demand in particular situations. Therefore, the organism diversity, both in the habitat and population, will turn the $\mathrm{PE}$ in the rehabilitation zone to its original function. The social diversity means that every individual must find solutions and ways to do something locally. Centralistic structures tend to create unity through controlling and bureaucracy regulation, while a diverse system is much easier to achieve through a maximum decentralization to take a decision, resources control, economic activities, and so forth.

In relation with Green's ecological perspective with his four principles, it gives significant usage and benefits; it requires decentralization with specific limitation to not let the farmers' community become arrogant, yet it is still necessary to build the institution. Institutions provide boundaries in terms of formal regulations, norms, and values as well as controls and sanctions. Institutions provide behavioural limitation to their members on what to do and not to do. North (1994:360) defines the institution as a set of regulation that limits the humanly devised to develop structural interaction of the politic, economy, and social. Throughout history, the institution can minimize the humanly devise action and create orderliness, as well as reduce the uncertainty in conducting the exchange. In this context, the institution has three components, namely formal regulation, informal regulation, and enforcement mechanism. To be more specific, to manage the natural resources, BAPPENAS gives clear direction towards the cooperation principle, which includes the government, business field, and the community. The government has the authority to enable the regulation by arranging the legal basis, the business world provides jobs opportunity, and the community organizes the process (2006). 


\section{METHODS}

This study applied the qualitative approach to reveal, trace, and analyze the data. The research location was at Meru Betiri National Park in East Java. The informants consisted of crops farmer groups of the rehabilitation zone and the TNMB management of East Java. The primary data were through observation, interview, and Focus Group Discussion (FGD), while the secondary data were through documentation in the form of TNMB processed data. The data validation was through triangulation technique by crosschecking three data source, while data analysis was through Miles and Huberman descriptive technique, namely data collection, data display, verification, and condensation.

\section{The Scarcity of Farming Land}

The farmers were cutting down trees in TNMB forest, both by individual and group strengths. Purwanto, a crops farmer at Andongrejo village as one of the areas in the rehabilitation zone of TNMB, stated ;

"People use to cut down trees at

TNMB at any times in the past "

The similar thing also stated by Imam safi'i, a leader of Andongrejo village, as a common phenomenon in the community around the TNMB area;

"In the past, cutting down trees only depended on the individual strength and the support from family members; the more support one can get, the better land area they can achieve."

People get more farming land by cutting down trees in a forest, burning the wood, crops planting, area looting, moving the pathok (land sign), and selling the area to other farmers. Competition among farmers to get more area occurs by getting more members to work in the rehabilitation zone. Some signs indicate the farmers need more farming land such as planting crops, uprooting the protected plants, keeping the land by rejection towards seeds from the TNMB, and planting forbidden plants by TNMB. The following is a figure of land expansion by planting crops:

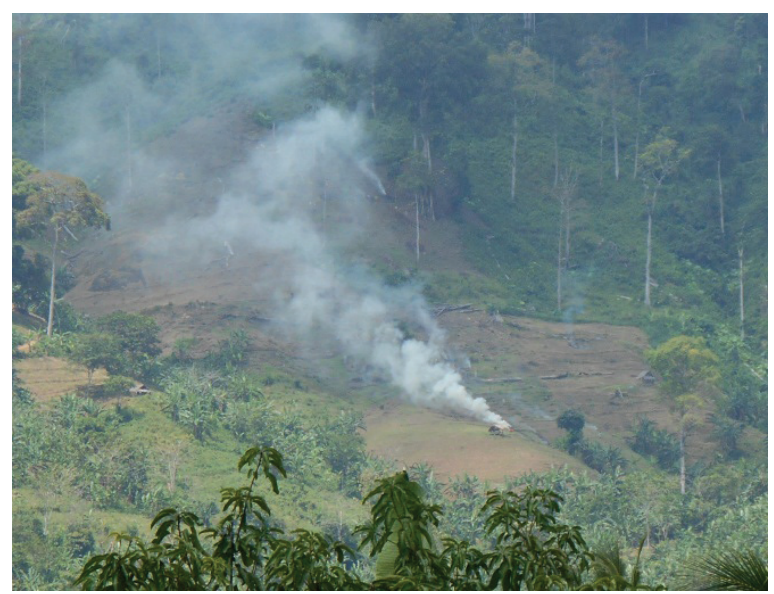

Fig. 1 Crops farmer expand the farming land by planting more crops and burning the forest

The complexion of this situation makes even the government officers have a strange personal impression from their official point of view. The following is a frustration expression by the TNMB Wonoasri Resort: 
"The central (government or higher leader) should comprehend the real issues on the filed to learn the demand and requirement from the farmers."

Another similar expression came from a member of Forest Guard Partner (MMP); TNMB only has limited seeds variant to plant, causing enthusiasm degeneration."

For this purpose, Peluso in Seda (2006:28) states " the forest guard from Perhutani experience internal subjective conflict that is against each other which is to plant and protect trees and to boost the village's economic growth." There are many forest guard from TNMB that is under terror and even conflict with the local farmers; they only try to perform their duty to control and enforce the law, while on the hand, the community wants to achieve farming land to support their lives."

The PE programs in the rehabilitation zone receive resistant from the crops farmers who have different needs. The contention is that TNMB wants to have reforestation by planting big trees in accordance to the current population in TNMB such as kluwak (Pangium edule), candlenut, bitter bean (Parkia speciosa), jackfruit, tamarind, kepuh, etc; while on the other hand, the local farmers want to plant seasonal plants such as banana, magone, Koro PJ, cassava, corn, and sort others. Therefore, there are conflicts between the TNMB officers and farmers due to different perception and economic and political purpose. Peluso in Seda (2006:26) stated that the environment turns out to be a battlefield of economy, politic, and ideology."

\section{Market Intervention}

The seasonal plants that initially came from the TNMB such as different kinds of herbs, little by little switched to other productive-best seller varieties due to market and crops farmers interventions. The market recommendation determines the seasonal plants' product price. In fact TNMB has the right to regulate things to do in the rehabilitation \one in accordance with the MoU. The situation will affect the crop farmers to obey less regulation from TNMB; even they dare to hiddenly fulfill the market demand, which gives more benefit to the farmers. Peluso in Seda (2006:27) stated that historically the society must learn about land and its use value, instead of the exchange value of the crops planted in the particular area. Consequently, the society will consider land to cultivate seasonal plants that are more consumable and provide more profit to support the farmers' economic need, instead of to plant big trees that require years to protect the environment as conservation forest." The farmers' mentality and needs are often opposed the TNMB programs as the conservation area; the farmers tend to think about current issues without considering the future. They are fighting against poverty. Some FGD participants at Andongrejo village said that "we keep plant whatever crops that give more benefit." The belief causes market intervention to penetrate the farmers' decision easily. 
The following is a statement from Mr. Yuli on the seasonal crops to meet the market demand:

“ I plant mango trees in the rehabilitation zone to offer to broker and let them harvest it."

Yuli, as the chief of Andongrejo farmers group, believes that involving broker is a common mechanism for land production. In short, this slight aspect is a peak of grand mechanism that change and mobilize the economic filed of farmers in rehabilitation zone, namely market, and commodification. What farmers believe as affording the family has expanded the meaning of commodity or having potential products. This situation causes the existent of a particular mechanism to distribute the commodity from the rehabilitation zone to support the farmers' activity. The following is a picture of market intervention in TNMB area, which determines the farmers' crop cultivation, namely koro PJ, which actually is prohibited by TNMB.

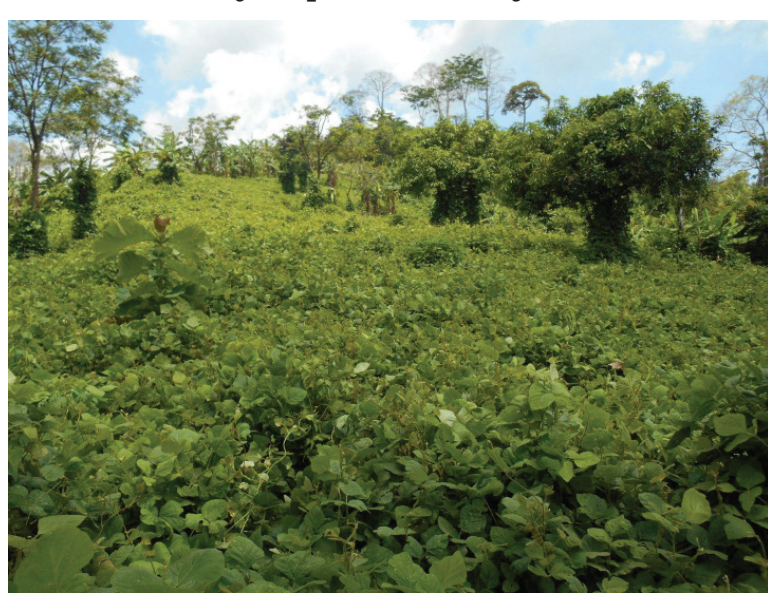

Fig. 2. Market intervention on farmers' choice to cultivate koro $P J$ crops.

The market mechanism intervention occurs not only in managing the rehabilitation zone but also in other conservation areas of TNMB. Illegal logging occurs due to individual demand and fulfilling limited individual needs. Cutting down trees is firmly attached to market demand. The illegal logging activity in TNMB common occurs because the demand for particular market actors such as furniture, house and ship construction, and woodcraft business. Peluso in Seda (2006:28) stated that the villagers are against control from outside, nevertheless the black market actors for teakwood and forestry agents whose action often strengthen a particular privilege based on ranks."

\section{Anthropocentric shift Abstinence}

Mr. Gozali, as the mosque caretaker and the elderly of Andongrejo village, informed that " Nowadays people no longer believe that the forest takes care the village." There is a self-awareness reflection that the surrounding ecosystem has changed and caused a dilemma of ignorance which results in the damage in the social environment. Mr. Gozali's statement shows that thin general, there is a philosophical linkage in the farming culture around TNMB area. There is a belief that the forest around their village is the guardian (rekso) of the ecosystem and social balance. The word sing ngrekso literally means to guard, and when it appears in a phrase namely hutan sing ngrekso; it means that nature is the center of all activities in the village. Nature (in this case is forests in TNMB) is, therefore, the caretaker of the village. Nevertheless, this prosperity meaning 
has changed as Gozali referred to the behavior of most other villagers.

The absence of belief that man lives in harmony with nature (the forest) encourages particular actions that show the implication of the previous philosophy of farming culture. The disappearance of previous farming culture can be in the form of burning protected trees from the part that is close to its roots, to kill the trees after a particular period of time by giving poison or cutting down the roots without notice, and cutting down trees' branches and prigs; leaving its main trunk as stated previously.

The abstinence related to taboos in the community is no longer exist. Forbidden forest, sacred areas, holy animals, holy trees, noble spirits; these beliefs seem to not exist in the buffering community anymore (Yuswadi \& Adi Bowo: ). Forest is no longer taboo for the farmers along with their arrogance to expand their land to plant seasonal crops.

People do not feel ashamed anymore to cut down trees even when it is considered as stealing act. The villagers are willing to abandon the social regulation on forest conservation," Once some villagers of Andongrejo took Daru wood from the national park, they carried the wood passing the village hall without worry or concern. In fact, only recently the forest guard caught a farmer took a piece of wood from the national park and tried to report it to the police but other villagers (almost all members of the neighborhood) came and defended him," said one of the village officer of Andongrejo.

The anthropocentric has changed the human ways to manage nature and other natural resources. Everything on earth is for humankind, that gives the rights to explore all resources; that human is the conquerer, and everything is to satisfy their desire. Dwi Susilo said that nature is no longer the objective of social activities; instead, it is merely a tool for personal purposes. The natural resources such as animals, plants, sand, water, air, and others are tools to achieve prosperity. The current human characteristic is to open new land (2008: 61).

The anthropocentric let human to do anything it takes for the current needs, especially economy, and leave the future alone without any concern. This belief will harm nature and result in natural damage in the future. People with anthropocentric ideology does come from not only well-educated level but also the poor as they are willing to do the same action without any consideration to damage the environment and nature. The following is rehabilitation zone that looks dry and arid, the protected trees are burnt and dying.

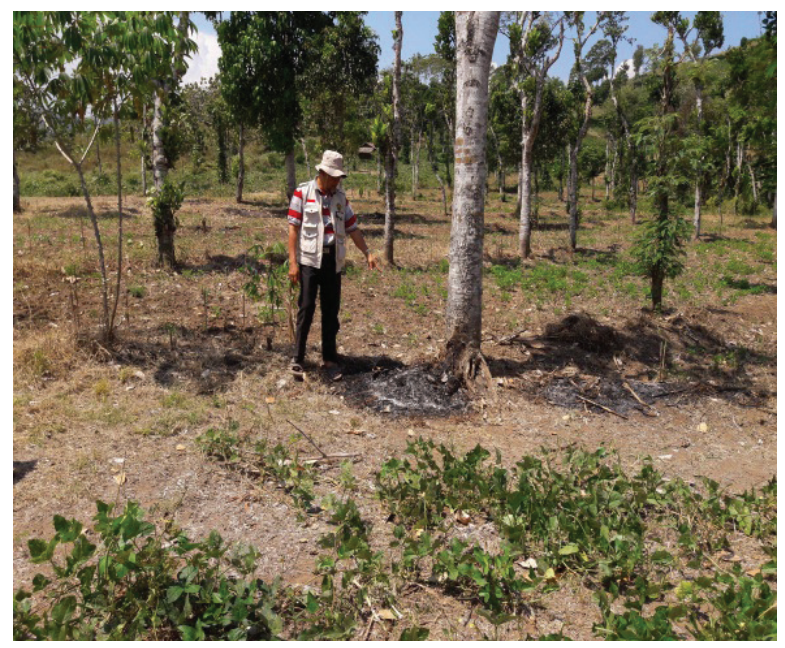

Fig.. 3. The dry and arid rehabilitation zone, the trees are burnt and dying. 
The human that at first consider the forest as a sacred place with spiritual values to keep the harmony living which causes humankind respect and protect, nowadays has changed to more rational resulting in the belief that everything exists for the individual purposes. Therefore, the human becomes the conquerer and exploit all natural resources, sell it to the free market. The trees trunk burning to kill the trees slowly is a form of the anthropocentric practice. P Illegal logging, crops planting that is not recommended by TNMB is the implementation of anthropocentric culture, which strengthens the commodification process.

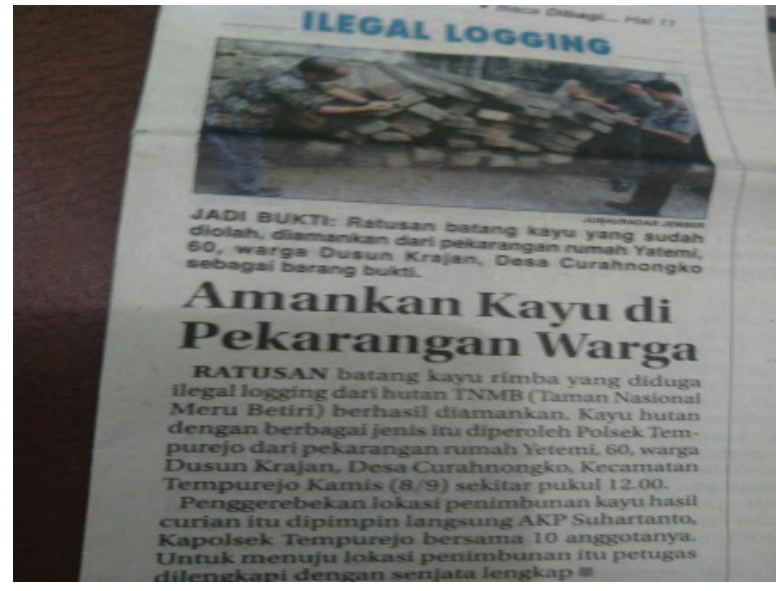

Fig.4 The police force of Jember is securing the woods from TNMB

\section{Empowerment Program}

The TNMB has been implementing the PE programs for crops farmers since 1999. The following are the PE programs initiated by TNMB.

Tabel 3 TNMB aids program for the Buffering Community Empowerment

\begin{tabular}{|c|l|l|l|}
\hline Year & \multicolumn{1}{|c|}{ Village } & \multicolumn{1}{|c|}{ Aids Type } & \multicolumn{1}{c|}{ Notes } \\
\hline 2011 & Wonoasri & $\begin{array}{l}\text { 1. Financial aids are to start } \\
\text { mushroom and herbs cultivation } \\
\text { 2. Financial aid is to develop the } \\
\text { cultivation of the herbs }\end{array}$ & $\begin{array}{l}\text { 3 packages (Each package } \\
\text { equals Rp.22.480.000) } \\
1 \text { package equals Rp. 8.160.000 }\end{array}$ \\
\hline 2011 & Andongrejo & $\begin{array}{l}\text { Financial aids to start up ginger } \\
\text { cultivation. }\end{array}$ & 1 packet Rp. 7.500.000 \\
\hline 2015 & Wonoasri & Annual program socialization & Rp. 20.150.000 \\
\hline & Andongrejo & Annual program socialization & Rp. 20.150.000 \\
\hline & Wonoasri & $\begin{array}{l}\text { Pieces of equipment to produce } \\
\text { organic fertilizer }\end{array}$ & 1 unit \\
\hline
\end{tabular}

Secondary data"statisctic source of BTNMB 2015.

The empowerment program by TNMB for the crops farmers aims at improving the farmers' income; therefore, they will not damage the TNMB area, especially the rehabilitation zone to ensure the PE program achieve an optimum result. Nevertheless, the programs were not successful due to the factors such as the scarcity farming land for the farmers, market

As stated in the previous explanation, the TNMB area, especially the rehabilitation zone, includes several stakeholders, namely the TNMB, crops farmers, LMDH, market, and furniture industry. Before institutionalize the 
empowerment of crops farmers, the needs of all stakeholders must be taken into account.

The expectation from TNMB through the $\mathrm{PE}$ programs is that the thousands of acre rehabilitation zone can gradually improve its ecosystem to the original purpose. On the other hand, the crops farmers need additional income through the empowerment program of herbs cultivation. They expect the herbs price is reasonable; therefore, it requires channeling with private sectors, traditional herbs medication factory, and another sector that needs the product. The design of the institution known as the interaction of cooperation eventually will slowly divert the crops farmers' attention on the exploration, illegal logging, and land burning to a productive and righteous human. Eventually, the market, furniture, ship construction, and statues' raw material businesses that have been intervening the farmers will lose their partners.

\section{The Built Institution}

There are several regulations according to Bappenas to manage the forest along with the community:

1. Clear definition of management limit

2. Legal apparatus, regulation, and enforcement.

3. To have a balance in exchanging information and knowledge.

4. Communication channel.

5. Monitoring mechanism among actors and other parties.
6. Graded sanction system.

7. Conflict resolution and decision change mechanism.

The land management in rehabilitation zone of TNMB that involves the buffering farmer community must in a detail plan to consider the different perception and understanding among farmers on the land. According to North, upon the community involvement, in managing the environment, it requires a broad understanding of the institution of land management. Different values, perception, and knowledge will result in the needs of institutional order. Upon the building of an institution, there will be less transaction cost due to the differences and inconsistency of framework (Bappenas: 2004).

Wibowo stated:

"The central government acts as the changing agent and innovation in society (initiator). With institution development approach (ID), the focus of government as changing agent remains still which resulting in the inability to achieve innovation. The government should initiate a discourse on the Institutional Sustainability (IS); government here as a facilitator instead of initiator“(Wibowo: 2009,73). 
Therefore, the economic institutional by TNMB has become a significant challenge to create institutional order that can overcome issues, both within and outside the community. The competition of interests involves a number of parties, namely: 1). The government, both central and regional; 2). Businessmen and investor whose business in natural resources; 3). The community who live in the exploitation area, and 4). Social organizations that care for environmental damage due to exploitation (Usman, 2001).

The Chart on Institutional Empowerment Building of Crops Farmers, namely cooperative interaction

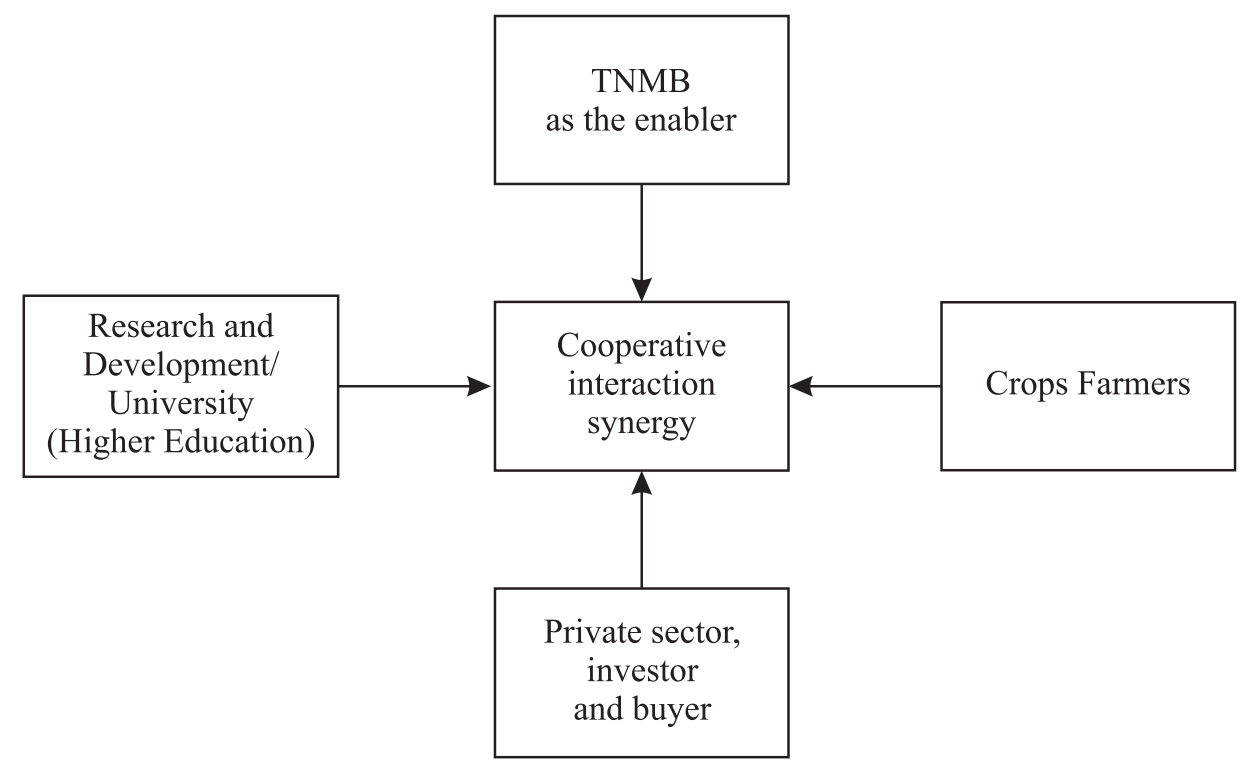

Chart 1. Institutional Empowerment of Crops Farmers in Rehabilitation Zone.

a. The government acts as enabler and facilitator that is to enforce the law, service standard, social infrastructure, and social security.

b. The crops farmers act as control and market that has social awareness. Social and politic interaction, selforganizing, solidarity agent, and the participation forum.

c. The private sector acts as the provider that is to provide job opportunities and income source, create product and service as well as to develop human resources (the traditional herbal medicine company ensures the proper flow from upstream to downstream for the farmers).

d. Higher Education and Research and Development act to ensure the quality of research and review on the program as well as supervising the crops farmers.

The institution finally ensured that each party interact and cooperate thoroughly to support the success of ecosystem returns in the TNMB rehabilitation area. Slowly, the crops farmers were no longer harming the protected trees, illegal logging, breaking down the protected seeds plant, and burning 
the forest to expand the farming area. The institutional of crops farmers will gradually ensure them to use the rehabilitation area in accordance to a collective agreement, benefit from yields legally, and eventually they will reject the market intervention on woods as raw material and also forbidden plants supply.

\section{CONCLUSION}

1. The crops farmers existed due to the scarcity of farmland; on the hand, these people need to afford their life. They resisted the ecosystem restoration program in rehabilitation zone by pulling out the protected plant seeds, slashing, planting crops, burning the forest land, cultivating the forbidden seasonal plant, and even conducting illegal logging.

2. The crops farmers did the damaging actions mostly due to the intervention of the market, which included the seasonal farming market, furniture mafia, and other woodcraft industries.

3. The Ecosystem Restoration programs in rehabilitation zone have started since 2003, but it still fails to reach the maximum achievement despite all empowerment programs for the buffering farmers.

4. There is a need to synergize the empowerment programs for the crops farmers with a network, namely cooperative interaction institution, through seasonal plants in the rehabilitation zone. The programs of herbal seeds by TNMB need excellent linkage with other stakeholders, namely the private sector (traditional herb medicine), higher education/research and development, and others. Last, the government must remain to run its function as the enabler and facilitator, while the private sector as the provider, and the community as the job seeker and control.

\section{Reference List}

Bappenas, 2004. Rencana Nasional Penanggulangan Bencana 2010 - 2014. Jakarta: Bappenas

Dharmawan, Arya Hadi. 2001. Farm Household Livelihood Strategies and Socio-economic Changes in Rural Indonesia: A Comparative Study. Socioeconomic Studies on Rural Development, Vol. 124, Wissenschaftsverlag Vauk Kiel KG

Dwi Susilo, Racmad. 2008. Sosiologi Lingkungan. Jakarta: Radjawali Pers.

Goeltenboth, Friedhelm., 1992. "Kerusakan Hutan dan Implikasi bagi Kesinambungan Daya Dukung Lingkungan. Prisma, No.6, Tahun XXI. Jakarta: LP3ES Giddens,Anthony.2011. The Constitution of society, teori 
Strukturasi untuk Analisis Sosial. Yogyakarta :Pedati.

Jim, Tosiereo and Tesoriero. 2008. Community

Development.

Jakarta:Pustaka Pelajar.

- 2006. Pembangunan Sosial dan Lingkungan Jurnal Masyarakat. ISSN-0852-8489. Jakarta: Departemen Sosiologi Universitas Indonesia

Lestari. 2009. Pengelolaan Sampah Berkelanjutan Berbasis Masyarakat. Monograf. ISBN 978-970-18431-7-1. Jakarta: Program Pasca Sarjana Departemen Sosiologi Fakultas Ilmu Sosial dan Ilmu Politik Universitas Indonesia.

Manig, Winfried. 1992. Structural and Institutional Changes in Rural Northwest Pakistan: The Journal of Development Studies. Vol. XII: 1-20

North, 1995. The New Institutional Economics and Third World Development. John Harris, Janet Hunter, and Colin M. Lewis. (eds.). The New Institutional Economics and Third World Development. London: Routledge.

Pelly, Usman. 1993. Pengukuran Intensitas Potensi Konflik dalam Masyarakat Majemuk, Analisis CSIS. Th.XXII, No. 3, Mei - Juni.
Rutherford, Malcolm. 1994. Institutions in Economics: The Old and the New Institutionalism. Cambridge: Cambridge University Press.

Sutopo, H.B. 2003. Pengumpulan dan Pengolahan Data dalam Penelitian Kualitatif. Dalam Masykuri Bakri. (ed.). Metodologi Penelitian Kualitatif: Tinjauan Teoritis dan Praktis. Malang: Lembaga Penelitian Universitas Islam Malang dan Visipres.

Usman, Sunyoto. 2001. Konflik dan Resolusi Konflik Sumberdaya Alam Perspektif Sosiologi, Pidato Pengukuhan Jabatan Guru Besar pada Fakultas Ilmu Sosial dan Ilmu Politik Universitas Gadjah Mada. Tgl. 15 September 2001.

Wibowo,Samudro. 2004. Administrasi negara Isu-isu Kontemporers. Yogyakarta: Graha Ilmu.

Yuswadi., dan Adi Bowo. Pemberdayaan Kelembagaan Tradisioanl Masyarakat Daerah Penyangga Hutan Untuk Pelestarian Taman Nasional Meru Betiri. http://kelembagaandas. wordpress.com/kelembagaantradisional/hari-yuswadi-dancahyoadi-bowo/ (download: 11-3-2013)

Anonim: Statistik BTNMB,2015, Jember: Kantor TNMB 